\title{
Low frequency breathing at rest and during exercise in severe chronic obstructive bronchitis ${ }^{1}$
}

\author{
R SERGYSELS, R WILLEPUT, D LENDERS, J-P VACHAUDEZ, W SCHANDEVYL, AND \\ A HENNEBERT
}

From the Clinique Dr Derscheid, B 1410 Waterloo-La Hulpe, Belgium

\begin{abstract}
The effect of low frequency breathing compared with spontaneous breathing was examined at rest and during exercise ( 40 watts) in 12 patients suffering from severe chronic obstructive bronchitis. At rest low frequency breathing improved significantly the alveolar ventilation and the tensions of oxygen and carbon dioxide in the arterial blood. There was no significant change in ventilation minute volume. During exercise low frequency breathing significantly decreased ventilation minute volume, and there was no significant improvement in gas exchange. The decrease in ventilation during low frequency breathing at 40 watts compared with spontaneous breathing at the same lung volume was due to expiratory flow limitation. The findings suggest that this technique may impair exercise tolerance in patients with severe chronic obstructive bronchitis.
\end{abstract}

Low frequency breathing (LFB) has been re-from chronic obstructive bronchitis; most of them $\stackrel{\mathbb{D}}{\mathbb{D}}$ commended for patients suffering from chronic obstructive bronchitis. At rest this pattern of breathing, characterised by low respiratory frequency and increased tidal volume improves alveolar ventilation and therefore gas exchange (Motley, 1963; Lockhart, et al, 1966; Paul et al, 1966; Gimenez, 1968; Sergysels et al, 1973). The effect, however, lasts only for the time the new ventilation pattern is maintained, and it is unclear how many patients will be able to adopt the pattern in their daily life. In particular patients suffering from airways obstruction whose ventilation approaches their maximal ventilatory capacity during moderate exercise (Cotes, 1965) may have difficulty preserving their ventilation during breathing with reduced frequency. To examine this aspect 12 patients suffering from severe chronic obstructive lung disease were trained to lower their respiratory frequency at rest and during exercise on a cycle ergometer. Ventilation $(\dot{V})$, alveolar ventilation (VA), and gas exchange were measured during spontaneous and during low frequency breathing.

\section{Methods}

The 12 patients included in the study were all suffering

'Presented at the Joint Meeting of Thoracic Societies, Bruges, Belgium, 20-21 April 1978. showed radiological evidence of emphysema. The $\overrightarrow{\vec{P}}$ ventilatory capacity was impaired. At rest, the $\frac{\circ}{3}$ patients were hypoxic $\left(\mathrm{PaO}_{2}<70 \mathrm{mmHg}\right)$, and nine of them were hypercapnic $\left(\mathrm{PaCO}_{2}>45 \mathrm{mmHg}\right)$. These and other details of the subjects are given in table 1 . Values for lung volumes were related to the reference values of Grimby and Söderholm, 1963.

After local anaesthesia, a cannula was inserted in the brachial artery for measuring $\mathrm{PaO}_{2}, \mathrm{PaCO}_{2}$, and $\stackrel{3}{3}$. pH (Radiometer). Ventilation $(\dot{V})$, respiratory 8 frequency (fR), and tidal volume (Vt) were measured $₹$ using a Fleish pneumotachograph. The mixed 음 expired gas was analysed for $\mathrm{CO}_{2}$ and $\mathrm{O}_{2}$ using respectively Jaeger and Servomex gas analysers. 을 From these data the $\mathrm{O}_{2}$ uptake and $\mathrm{CO}_{2}$ output (respectively $\dot{\mathrm{V}}_{2}$ and $\dot{\mathrm{V}}_{2}$ ) and the relation of the o) alveolar to the total ventilation $(\dot{V} A / \dot{V})$ were calcula- $N$ ted. At rest during spontaneous breathing, the measurements were made under steady state con- $O$ ditions at the end of an eight-minute period of observation. The patients then lowered their respira- $\frac{\bar{D}}{\mathrm{D}}$ tory frequency (to about $8 \mathrm{~min}^{-1}$ ), and the measure- $\stackrel{\infty}{+}$ ments were repeated.

The subjects were subsequently exercised on a

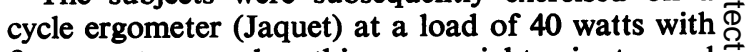
first spontaneous breathing over eight minutes and $\mathbb{\mathbb { D }}$ then, after a 20-minute rest, with LFB. Tidal volume $\frac{O}{\sigma}$ was again roughly doubled but respiratory frequency was never lower than $10 \mathrm{~min}^{-1}$. 
Table 1 Spirometric values and blood gases at rest. Values for lung volumes are referred to normals established by Grimby (mean and $S D ; n=12$ )

\begin{tabular}{|c|c|c|c|c|c|c|c|c|c|c|}
\hline & $\begin{array}{l}\text { Age } \\
(y r)\end{array}$ & $\begin{array}{l}V C \\
(\% \text { predicted })\end{array}$ & $\begin{array}{l}T L C \\
\% \text { predicted }\end{array}$ & $\begin{array}{l}R V \\
(\% \text { predicted }\end{array}$ & $\underset{l(m l)}{F E V_{1}}$ & $\begin{array}{l}F E V_{1} / V C \\
(\%)\end{array}$ & $\frac{\begin{array}{l}R a w \\
\mathrm{~cm} \mathrm{H} \mathrm{H}_{2} \mathrm{O}\end{array}}{\mathrm{l} / \mathrm{s}}$ & $p H$ & $\begin{array}{l}\mathrm{PaCO}_{2} \\
(\mathrm{mmHg})\end{array}$ & $\begin{array}{l}\mathrm{PaO}_{2} \\
(\mathrm{mmHg})\end{array}$ \\
\hline Mean & $52 \cdot 6$ & 63.4 & $97 \cdot 5$ & $184 \cdot 3$ & 1025 & $35 \cdot 5$ & $6 \cdot 25$ & $7 \cdot 38$ & $47 \cdot 6$ & 58.9 \\
\hline SD & $8 \cdot 7$ & $15 \cdot 9$ & $18 \cdot 0$ & $32 \cdot 1$ & 360 & $8 \cdot 2$ & 1.69 & 0.03 & $5 \cdot 3$ & $7 \cdot 8$ \\
\hline
\end{tabular}

\section{Results}

Table 2 summarises the results obtained at rest and during exercise during spontaneous and low frequency breathing.

\section{At rest}

With LFB the mean respiratory frequency was lowered from $21.9 \mathrm{~min}^{-1}$ to $10.2 \mathrm{~min}^{-1}$ and the tidal volume increased from $544.6 \mathrm{ml}$ to $1122 \mathrm{ml}$, but total ventilation remaining unchanged.

Tidal volume expressed as a percentage of $\mathrm{FEV}_{1}$ and of VC was respectively $58 \cdot 3 \%$ and $20.3 \%$ during SB and $110 \cdot 2 \%$ and $38.1 \%$ during LFB.

$\dot{\mathrm{V}} \mathrm{O}_{2}$ remained unchanged while $\dot{\mathrm{V}} \mathrm{CO}_{2}$ increased during LFB.

With LFB, $\dot{V} A$ and $\dot{V} A$ increased significantly, leading to a small but significant increase in $\mathrm{PaO}_{2}$ and decrease in $\mathrm{PaCO}_{2}$.

\section{Exercise}

Exercise induced an increase in $\dot{V} A$ and $\frac{\dot{V} A}{\dot{V}}$ but despite this during SB most patients incurred a small decrease in $\mathrm{PaO}_{2}$ and increase in $\mathrm{PaCO}_{2}$. During $\mathrm{LFB}, \mathrm{Vt}$ was again roughly doubled going from $877 \mathrm{ml}$ to $1552 \mathrm{ml}$ while frequency was lowered from $28.7 \mathrm{~min}^{-1}$ to $15 \cdot 3 \mathrm{~min}^{-1}$. Ventilation minute volume decreased from $24.51 / \mathrm{min}$ to $21 \cdot 6 \mathrm{l} / \mathrm{min} \frac{\mathrm{Vt} \%}{\mathrm{FEV}_{1}} \frac{\text { and }}{\mathrm{VC}}$ were respectively $90.3 \%$ and $31.4 \%$ during SB and reached $153.1 \%$ and $53.7 \%$ during LFB.

Changes in $\dot{\mathrm{VO}}_{2}$ and $\mathrm{V}_{\mathrm{CO}}$ were not significant. LFB resulted in a small increase in VA and slight reduction in $\mathrm{PaCO}_{2}$. There was no significant change in $\mathrm{PaO}_{2}$.

\section{Discussion}

This study confirms the finding of others that at rest LFB with or without pursed lips increases the alveolar ventilation and this improves gas exchange of respiratory patients with chronic hypoxia and hypercapnia (Lockhart et al, 1966; Thoman et al, 1966; Sergysels et al, 1973). A similar improvement has been reported during exercise (Jimenez, 1968), but the patients had less impairment of lung function than in this study.

During pursed lip breathing Mueler et al (1970) obtained similar findings at rest. During exercise ventilation fell from $27.61 \mathrm{~min}^{-1}$ to $22.81 \mathrm{~min}^{-1}$, and there was no significant change in $\mathrm{PaO}_{2}$ or $\mathrm{PaCO}_{2}$.

During LFB, patients in our study were able to bicycle for eight minutes at 40 watts without subjective discomfort. Only two of the 12 patients, however, were able to maintain the ventilation at its normal level. Five of the 12 patients showed a significant

Table 2 Data obtained at rest and during exercise (40watts) with spontaneous breathing (SB) and low frequency breathing $(L F B)$. Mean and $S D$ are presented; values at rest and at 40 watts are statistically analysed with paired test

\begin{tabular}{|c|c|c|c|c|c|c|c|c|c|c|c|c|}
\hline & & & $\begin{array}{l}\dot{V} E \\
(l / \min )\end{array}$ & $f$ & $\begin{array}{l}V t \\
(m l)\end{array}$ & $\begin{array}{l}\dot{V} \mathrm{O}_{2} \\
(\mathrm{ml} / \mathrm{min})\end{array}$ & $\begin{array}{l}\dot{V} \mathrm{CO}_{2} \\
(\mathrm{ml} / \mathrm{min})\end{array}$ & $\begin{array}{l}\dot{V} A \\
(l)\end{array}$ & $\begin{array}{l}\dot{V} A / V \\
(\%)\end{array}$ & $p H$ & $\begin{array}{l}\mathrm{PaCO}_{2} \\
(\mathrm{mmHg})\end{array}$ & $\begin{array}{l}\mathrm{PaO}_{2} \\
(\mathrm{mmHg})\end{array}$ \\
\hline & SB & $\begin{array}{l}\text { Mean } \\
\text { SD }\end{array}$ & $\begin{array}{r}11 \cdot 249 \\
1 \cdot 729\end{array}$ & $\begin{array}{r}21 \cdot 9 \\
5 \cdot 6\end{array}$ & $\begin{array}{l}544 \cdot 6 \\
164 \cdot 0\end{array}$ & $\begin{array}{r}278 \cdot 9 \\
45 \cdot 2\end{array}$ & $\begin{array}{r}238.4 \\
39 \cdot 0\end{array}$ & $\begin{array}{l}4 \cdot 378 \\
0.951\end{array}$ & $\begin{array}{r}38 \cdot 3 \\
6 \cdot 4\end{array}$ & $\begin{array}{l}7 \cdot 38 \\
0 \cdot 03\end{array}$ & $\begin{array}{r}47 \cdot 6 \\
5 \cdot 3\end{array}$ & $\begin{array}{r}58 \cdot 9 \\
7 \cdot 8\end{array}$ \\
\hline \multirow[t]{2}{*}{ At rest } & LFB & $\begin{array}{l}\text { Mean } \\
\text { SD } \\
\mathbf{P}\end{array}$ & $\begin{array}{r}10 \cdot 801 \\
N S^{3 \cdot 133}\end{array}$ & $\begin{array}{l}10 \cdot 2 \\
2 \cdot 9 \\
<\quad 0.0005\end{array}$ & $\begin{array}{c}1122 \cdot 0 \\
469 \cdot 0 \\
<0 \cdot 0025\end{array}$ & $\begin{array}{r}292.4 \\
\text { NS }\end{array}$ & $\begin{array}{c}277.1 \\
60.6 \\
<\quad 0.01\end{array}$ & $\begin{array}{l}5.930 \\
2.482 \\
<\quad 0.0125\end{array}$ & $\begin{array}{l}52 \cdot 1 \\
9 \cdot 7 \\
<\quad 0.0005\end{array}$ & $\begin{array}{c}7.42 \\
0.04 \\
<0.005\end{array}$ & $\begin{array}{l}42.9 \\
7.7 \\
<0.005\end{array}$ & $\begin{array}{l}63 \cdot 5 \\
9 \cdot 2 \\
<\quad 0.0125\end{array}$ \\
\hline & SB & $\begin{array}{l}\text { Mean } \\
\text { SD }\end{array}$ & $\begin{array}{r}24 \cdot 500 \\
3 \cdot 400\end{array}$ & $\begin{array}{r}28 \cdot 7 \\
6 \cdot 6\end{array}$ & $\begin{array}{l}877 \cdot 0 \\
220 \cdot 0\end{array}$ & $\begin{array}{r}698 \\
79\end{array}$ & $\begin{array}{l}662 \\
114\end{array}$ & $\begin{array}{r}11 \cdot 326 \\
2 \cdot 824\end{array}$ & $\begin{array}{l}47 \cdot 1 \\
10 \cdot 4\end{array}$ & $\begin{array}{l}7 \cdot 34 \\
0 \cdot 02\end{array}$ & $\begin{array}{r}51 \cdot 6 \\
6 \cdot 7\end{array}$ & $\begin{array}{l}56 \cdot 0 \\
10 \cdot 2\end{array}$ \\
\hline 40 Watts & LFB & $\begin{array}{l}\text { Mean } \\
\text { SD } \\
P\end{array}$ & $\begin{aligned} & 21 \cdot 580 \\
& 3 \cdot 220 \\
&< 0 \cdot 0025\end{aligned}$ & $\begin{array}{l}15 \cdot 3 \\
5 \cdot 3 \\
<0 \cdot 0005\end{array}$ & $\begin{array}{c}1552 \cdot 0 \\
497.0 \\
<0.005\end{array}$ & $\begin{array}{r}722 \\
103 \\
\text { NS }\end{array}$ & $\begin{array}{r}721 \\
165 \\
\text { NS }\end{array}$ & $\begin{array}{l}12 \cdot 868 \\
4.070 \\
<\quad 0.0125\end{array}$ & $\begin{array}{c}58 \cdot 7 \\
13 \cdot 4 \\
<\quad 0.0005\end{array}$ & 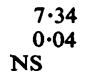 & $\begin{aligned} & 49.7 \\
& 6.3 \\
< & 0.025\end{aligned}$ & $\begin{array}{r}56 \cdot 0 \\
N^{9 \cdot 6}\end{array}$ \\
\hline
\end{tabular}


increase in VA while in two there was a decrease. On average LFB increased VA by $36 \%$ at rest but only by $20 \%$ during exercise. The absence of a worthwhile improvement in gas exchange could be explained at least in part by the relative decrease in ventilation.

Grimby and Stiksa (1970) showed that patients with chronic obstructive bronchitis increased their end expiratory level during exercise and on this account were able to generate higher expiratory flows. This tendency would be modified by low frequency breathing when, as in this study, $\mathrm{Vt}$ reached $53 \%$ of VC. In one subject flow-volume loops recorded during spontaneous breathing at rest and during exercise with spontaneous and low frequency breathing were located in a maximal flow volume curve obtained during forced vital capacity (FVC) manoeuvre (see figure). Exercise with spontaneous breathing induced an upwards shift of the end expiratory level. LFB lowered the end expiratory level nearly to the FRC level observed at rest during spontaneous breathing.

At isovolume and therefore at isodriving force, flows recorded during spontaneous breathing both at

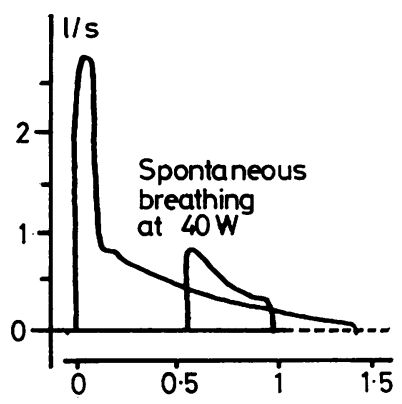

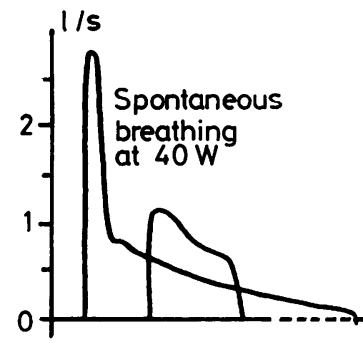

$\dot{V} E=29.561 / \mathrm{min}$

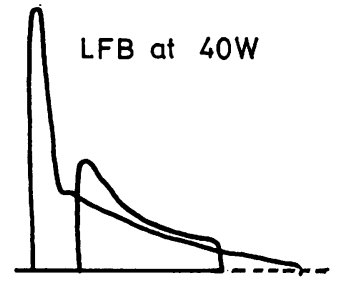

VE $=20.42 \mathrm{l} / \mathrm{min}$
In one subject, expiratory flow volume loops were obtained at rest, during spontaneous breathing at 40 watts and during $L F B$ at 40 watts and located in a maximal expiratory flow volume curve (MEFV) obtained at rest. At rest expiratory flows exceeded those recorded during a MEFV. This became even more obvious during exercise with spontaneous breathing. $L F B$ at 40 watts was characterised by a downward shift of end expiratory level and a significant reduction of an expiratory flow when compared to spontaneous breathing. rest and on exercise are higher than during forced expiration. During exercise, expiratory flows were $\frac{\bar{\sigma}}{\circ}$ higher with spontaneous than with low frequency $\frac{\bar{\sigma}}{\bar{s}}$ breathing. At the same time the ventilation decreased $\vec{\nabla}$ from $29.51 \mathrm{~min}^{-1}$ to $20.41 \mathrm{~min}^{-1}$.

Ventilation can be expressed as the product of क $\mathrm{Vt} \times \mathrm{TE} \times 60$ where TE is the expiratory time and $\overrightarrow{0}$ $\overline{\mathrm{TE}} \overline{\mathrm{Tt}} \mathrm{t}$

$T_{\text {Tо }}$ the sum of TE and the inspiratory time (TI). Vt and TE were respectively $0.77,0.64$ during $\vec{x}$ $\overline{\mathrm{TE}} \quad \overline{\mathrm{Tt}} \mathrm{t}$

spontaneous and $0.44,0.74$ during low frequency breathing (see figure). Clearly, the decrease in Vt if

(that is the mean expiratory flow) was the determining 음 factor of the relative limitation of $\dot{V}$ observed with $\overrightarrow{ }$ LFB.

These findings show that lowering the respiratory frequency during exercise in patients with severe क chronic obstructive bronchitis may not result in the $\vec{\varphi}$ expected improvement in gas exchange: instead there may be relative hypoventilation for mechanical reasons. This is due to the associated reduction in resting respiratory level diminishing the airways calibre and the force available for expiration. Thus any patient suffering from chronic airways obstruction should be investigated from this point of view before being instructed to breathe slowly during daily activities such as walking or climbing stairs.

\section{References}

Cotes, J E (1965). Factors which limit exercise. In Lung Function Assessment and Application in Medicine, pp 250-268. Blackwell, London.

Grimby, G, and Söderholm, B (1963). Spirometric studies in normal subjects. Acta Medica, Scandinavica, 173, 199-206.

Grimby, G, and Stiksa, J (1970). Flow-volume curves and breathing patterns during exercise in patients with obstructive lung disease. Scandinavian Journal of Clinical and Laboratory Investigation, 25, 303-313.

Jimenez, M (1968). La ventilation dirigée au cours de l'insuffisance respiratoire chronique. Technique, physiopathologie et résultats au repos et au cours de l'exercice musculaire. Thèse Médicale, Nancy.

Lockhart, A, Jimenez, M, Schrijen, F, and Vittoz, E (1966). Etude physiopathologique de la kinésithérapie respiratoire dans les bronchopneumopathies chroniques. Bulletin Physio-pathologie Respiratoire, 2, 237-252.

Motley, H L (1963). The effects of slow deep breathing on the blood gas exchange in emphysema. American Review of Respiratory Disease, 88, 484-492.

Mueler, R E, Petty, T L, and Filley, G F (1970). Ventilation and arterial blood gas changes induced by pursed lips breathing. Journal of Applied Physiology, 28, 784-789.

Paul, G, Eldridge, F, Mitchell, J, and Fiene, T (1966). Some effects of slowing respiration rate in chronic

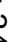


emphysema and bronchitis. Journal of Applied Physiology, 21, 877-882.

Sergysels, R, Willeput, R, Lenders, D, Vachaudez, J-P, Knoops, Th, and Hennebert, A (1973). La ventilation dirigée appliquée aux bronchopathies chroniques obstructives. Etude fonctionnelle. Revue Geminaire Belge de Readaption, 15, 228-238.
Thoman, R L, Stoker, G L, and Ross J C (1966). The efficacy of pursed-lips breathing in patients with chronic obstructive pulmonary disease. American Review of Respiratory Disease, 93, 100-106.

Requests for reprints to: Dr $\mathbf{R}$ Sergysels, Clinique de Derscheid, B1410 Waterloo-La Hulpe. 